\title{
ISOLASI FLAVONOID DARI BIJI KAKAO (Theobroma cacao)
}

\author{
Bustanul Arifin*, Afrizal, Hasnirwan, Rio Rinaldo \\ Laboratorium Kimia Organik Bahan Alam, Jurusan Kimia FMIPA, \\ Universitas Andalas Padang \\ email : ba_arifin@yahoo.co.id
}

\begin{abstract}
ABSTRAK
Telah dilakukan isolasi senyawa flavonoid dari biji cacao (Theobroma cacao) pada fraksi etil asetat. Isolasi dilakukan dengan maserasi menggunakan metanol dan dilakukan fraksinasi dengan n-heksan dan etil asetat. Fraksi etil asetat dilakukan kolom kromatografi bertekanan tinggi (flash colom chromatografphy). Hasil isolasi berupa kristal bewarna kuning dan telah memberikan noda tunggal dengan beberapa eluen menggunakan kromatografi lapisan tipis (TLC). Kromatografi kertas dua arah didapatkan Rf 0,45 menggunakan eluen BAA (4:1:5) dan Rf 0,48 menggunakan eluen asam asetat 15\%. Spektroskopi ultraviolet dengan menggunakan pelarut metanol memberikan serapan pada $\lambda_{\text {maks }} 281$ dan $328 \mathrm{~nm}$. Menggunakan pereaksi geser $\mathrm{NaOCH}_{3}$ serapan $\lambda_{\text {maks }} 290$ dan $411 \mathrm{~nm}, \mathrm{AlCl}_{3} \lambda_{\text {maks }} 293$ dan $385 \mathrm{~nm}$ dan $\mathrm{HCl} \lambda_{\text {maks }} 280$ dan $330 \mathrm{~nm}, \mathrm{NaOOCCH}_{3}$ serapan $\lambda_{\text {maks }} 281$ dan $330 \mathrm{~nm}$ dan $\mathrm{H}_{3} \mathrm{BO}_{3}$ serapan $\lambda_{\text {maks }} 295$ dan $381 \mathrm{~nm}$. Spektroskopi infra merah (IR) memberikan serapan pada angka gelombang 3407,6; 2360,4; 1663,3; 409,8 $\mathrm{cm}^{-1}$. Berdasarkan data tersebut diperkirakan senyawa hasil isolasi dari $\lambda_{\text {maks }} 281$ dan $328 \mathrm{~nm}$ adalah suatu flavonol yang tersubstitusi dengan gugus hidroksi pada posisi 7, 3' dan 4'.
\end{abstract}

Kata kunci: isolasi, flavonoid, cacao

\section{PENDAHULUAN}

Kekayaan alam yang melimpah pada sumber daya alam hayati, telah dimanfaatkan oleh masyarakat Indonesia untuk berbagai keperluan, antara lain sebagai bahan baku industri, pangan dan sebagai obat. Banyak jenis tumbuhan yang sudah dimanfaatkan sejak lama sebagai makanan dan obat-obatan tradisional tapi belum diketahui senyawa kimia yang terkandung di dalamnya (Gunawan dkk, 1983; Achmad dkk, 1990).

Penggunaan tumbuhan obat untuk menyembuhkan berbagai macam penyakit telah lama dilakukan manusia. Hal ini mendorong para ahli untuk mengkaji kandungan tumbuhan tersebut yang berperan sebagai sumber obat. Sampai saat ini masih banyak potensi tumbuhan obat yang belum diteliti. Dari sekian banyak spesies tumbuhan, hanya sedikit yang telah dikaji secara fitokimia dan lebih sedikit lagi yang telah mengkaji aktivitas biologis dan farmakologisnya (Gunawan dkk, 1983; Achmad dkk, 1990).
Kandungan kimia yang memberikan efek fisiologi dan farmakologi lebih dikenal dengan senyawa aktif. Senyawa aktif ini merupakan hasil metabolisme sekunder dari tumbuhan itu sendiri dimana penyebaran dan jumlahnya dalam tiap bagian tumbuhan tidak sama. Hal ini mendorong para ahli untuk melakukan penelitian tentang isolasi, sintesis, uji bioaktifitas dan pemanfaatannya lebih lanjut (Gunawan dkk, 1983; Achmad dkk, 1990; Geissman, 1962).

Salah satu tumbuhan yang digunakan sebagai bahan makanan dan obat tradisional adalah biji kakao. Bagian biji kakao banyak dimanfaatkan oleh masyarakat yang berguna sebagai antioksidan yang dapat mengurangi pembentukan radikal bebas penyebab kanker. Kakao juga mengandung senyawa bioaktif yang bermanfaat mencegah terjadinya penimbunan kolesterol pada dinding pembuluh darah (Achmad dkk, 1990).

Biji kakao mengandung banyak senyawa kimia seperti glukosa, fruktosa, sukrosa, tanin, lemak dan protein. Sedangkan 
metabolit sekunder yang ada pada tanaman ini seperti steroid, terpenoid, fenolik, kumarin, alkaloid dan flavonoid. Penelitian yang telah dilaporkan bahwa dalam biji kakao terdapat flavonoid, merupakan antioksida yang sangat bagus (Achmad dkk, 1990).

Berdasarkan hal tersebut di atas serta kandungan senyawa aktif yang telah dilaporkan, maka penelitian ini dilakukan untuk mengisolasi salah satu dari senyawa metabolit sekunder tersebut yaitu flavonoid. Penelitian ini dilakukan dengan metoda ekstraksi secara maserasi dengan menggunakan pelarut metanol, fraksinasi dengan n-heksan dan etil asetat, pemisahan dan pemurnian komponen kimia dengan kromatografi, serta karakteristisasi senyawa dengan melakukan pemeriksaan secara konvensional dan spektrofotometri.

Penelitian ini bertujuan untuk mengisolasi, mengidentifikasi dan mengkarakterisasi senyawa flavonoid dari biji kakao (Theobroma cacao). Masalah yang dibahas pada penelitian ini adalah mengisolasi senyawa flavonoid. kemudian diidentifikasi jenis flavonoid yang didapatkan. Jenis flavonoid hasil isolasi dikarakterisasi untuk memperkirakan struktur senyawa tersebut.

\section{METODE PENELITIAN Alat dan Bahan}

Peralatan yang digunakan untuk pengerjaan isolasi adalah seperangkat alat distilasi, seperangkat alat rotary evaporator (Betracher Lamag), lemari pengering atau oven (Fisher Scientific Isotemp oven, model $630 \mathrm{~F}$ ), lampu $\operatorname{UV}(\lambda=254 \mathrm{~nm}$ dan $366 \mathrm{~nm})$, melting point apparatus (Fisher Jhon), spektrofotometer UV-Vis (Type UV-160 A; Shimadzu), kolom kromatografi $(50 \mathrm{~cm} \times 2,5 \mathrm{~cm}$ i.d), plat KLT (silika gel $60 \mathrm{~F}_{254}$ ), gelas ukur berbagai ukuran, botol berbagai ukuran, chamber, plat tetes, corong pisah, kapiler, alumunium foil, kromatografi kertas dan kertas saring.

Bahan-bahan yang digunakan untuk uji fitokimia adalah $\mathrm{HCl}$ pekat, logam $\mathrm{Mg}$, asam asetat, logam natrium, $\mathrm{AlCl}_{3}$, natrium asetat, $\mathrm{H}_{3} \mathrm{BO}_{3}$, aseton, akuades. Sedangkan bahanbahan untuk pengerjaan isolasi adalah biji kakao (Theobroma cacao), metanol, etil asetat, nheksana dan silika gel $60 \mathrm{~F}_{254}$.

\section{Persiapan Sampel}

Sampel diambil di kota Pariaman, Propinsi Sumatera Barat sebanyak 2 kg. Bagian yang diisolasi adalah biji kakao (Theobroma cacao).

\section{Uji Pendahuluan Flavonoid}

Sampel segar daun sebanyak 2 gram dipotong halus, dimasukkan ke dalam sebuah tabung reaksi, kemudian dimaserasi dengan metanol dan dipanaskan di atas penangas air selama 15 menit. Hasil maserasi dalam kondisi panas disaring dan dimasukan ke dalam tabung reaksi lainnya. Tambahkan beberapa tetes larutan $\mathrm{HCl}$ pekat dan beberapa butir bubuk $\mathrm{Mg}$ ke dalam ekstrak metanol. Terbentuknya warna merah menandakan adanya senyawa flavonoid (Harbone 1987a, 1987b; Harbone dkk 1975).

\section{Isolasi Senyawa Flavonoid}

Sampel dimaserasi pada temperatur kamar menggunakan pelarut metanol beberapa kali sampai ekstraksi sempurna. Hasil maserasi dipekatkan dengan rotary evaporator pada suhu $40^{\circ} \mathrm{C}$. Ekstrak pekat tersebut difraksinasi dengan n-heksana, kemudian dilanjutkan fraksi dengan etil asetat. Setiap fraksi yang didapatkan dilakukan uji terhadap senyawa flavonoid. Fraksi yang positif flavonoid (fraksi etil asetat) dipekatkan dengan rotary evaporator.

Ekstrak pekat dari fraksi etil asetat sebanyak 5 gram dilakukan kolom kromatografi bertekan tinggi menggunakan eluen n-heksana, etil asetat dan metanol dengan sistim kepolaran bertingkat. Hasil kromatografi kolom tersebut selanjutnya diuji dengan KLT dengan menggunakan pengungkap noda uap yodium. Untuk fraksi yang mempunyai pola noda dan harga Rf yang sama digabung menjadi satu fraksi dan selanjutnya dipekatkan dengan rotari evaporator. Frakri yang positif flavonoid dilakukan kolom kromatografo kembali dengan berbagai eluen dengan sistem kepolaran beryingkat.

Fraksi yang diperoleh dilakukan uji flavonoid dan dilakukan kromatografi kertas untuk menentukan adanya senyawa flavonoid. Fraksi yang positif terhadap uji flavonoid dimurnikan dengan kromatografi kertas preparatif menggunakan eluen n-butanol:asam asetat:air (4:1:5). Hasil isolasi senyawa yang didapatkan dilakukan karakterisasi untuk mengetahui strukturnya (Harbone 1987a, 1987b).

\section{Karakterisasi senyawa hasil isolasi} Untuk menentukan golongan flavonoid, hasil isolasi diperiksa dengan metoda 
kropmatografi kertas 2 arah, dengan eluen campuran n-butanol, asam asetat, dan air (4:1 : 5) serta asam asetat $15 \%$. Kemudian dibandingkan dengan kromatogram standar. Untuk menentukan strukturnya digunakan analisis spektroskopi spektrofotometer ultraviolet dan infra merah. Khusus untuk spektofotometer ultraviolet dilakukan penambahan pereaksi geser natrium metoksida $\left(\mathrm{NaOCH}_{3}\right)$, alumunium klorida/asam klorida $\left(\mathrm{AlCl}_{3} / \mathrm{HCl}\right)$ dan natrium asetat/asam borat $\left(\mathrm{NaOOCCH}_{3} / \mathrm{H}_{3} \mathrm{BO}_{3}\right)$ (Harbone 1987a, 1987b).

\section{HASIL DAN PEMBAHASAN}

Salah satu metabolit sekunder yang terdapat dalam sampel adalah senyawa flavonoid. Hal ini dibuktikan dengan Sianidin test menggunakan $\mathrm{HCl}$ pekat dan bubuk $\mathrm{Mg}$ menghasilkan warna merah muda. Fraksi etil asetat memberikan warna merah dengan pereaksi $\mathrm{Mg} / \mathrm{HCl}$ berarti mengandung senyawa flavonoid.

Fraksi etil asetat dilakukan kolom kromatografi, hasil kromatografi kolom ditampung dalam vial $10 \mathrm{~mL}$ dan di KLT. Berdasarkan hasil KLT, fraksi-fraksi yang memiliki pola noda dan $\mathrm{Rf}$ yang sama digabung diperoleh 8 fraksi. Fraksi yang mengandung flavonoid adalah fraksi 5, 6, dan 7, sedangkan fraksi lainnya mengandung flavonoid. Selanjutnya dilakukan pemurnian terhadap fraksi 5 dengan kromatografi kolom kembali dan diperoleh 4 fraksi. Fraksi yang mengandung flavonoid adalah fraksi 1, 2 dan 4 sedangkan fraksi 3 tidak mengandung flavonoid. Selanjutnya fraksi 1 dilakukan pemurnian dengan kromatografi kertas preparatif menggunakan eluen n-butanol:asam asetat:air (4:1:5).

Hasil kromatografi kertas preparatif diperoleh senyawa murni kristal/bubuk bewarna kuning. Senyawa hasil isolasi memberikan noda tunggal dengan eluen yaitu eluen n-heksana : etil asetat $(5: 5) \operatorname{Rf} 0,45$ eluen $n$-heksana : etil asetat $(2: 8) \operatorname{Rf} 0,55$ eluen etil asetat : aseton $(5: 5)$ Rf 0,75 serta etil asetat : metanol $(1: 1) \operatorname{Rf} 0,88$. Kromatografi kertas dua arah didapatkan $\mathrm{Rf}$ 0,45 menggunakan eluen BAA (4:1:5) dan Rf 0,48 menggunakan eluen asam asetat $15 \%$.

Sedangkan senyawa hasil isolasi memberikan puncak pada panjang gelombang $328 \mathrm{~nm}$ sebagai puncak I dan $281 \mathrm{~nm}$ sebagai puncak II. Bila menggunakan pereaksi geser maka akan berpeluang mengalami pergeseran panjang gelombang. Pada pita I terjadi pergeseran batokromik sebesar $83 \mathrm{~nm}$ dan pita II pergeseran batokromik sebesar $9 \mathrm{~nm}$, setelah penambahan pereaksi geser $\mathrm{NaOMe}$. Hal ini menindikasikan bahwa senyawa flavonoid hasil isolasi tidak memiliki gugus $-\mathrm{OH}$ yang tersubtitusi pada cincin B, kemungkinan adanya gugus hidroksi pada cincin $\mathrm{A}$.

Penambahan $\mathrm{AlCl}_{3}$ akan membentuk komplek yang tahan asam antara gugus hidroksi dan keton, dan komplek yang tidak tahan asam antara gugus hidroksi yang bertetangga (gugus orto-hidroksi). Jadi spektrum $\mathrm{AlCl}_{3}$ berguna untuk menditeksi 5-OH dan orto-dihidroksida. Sedangkan penambahan $\mathrm{HCl}$ akan memutus kompleks yang tidak tahan asam, jadi spektrum $\mathrm{AlCl}_{3} / \mathrm{HCl}$ hanya merupakan pengaruh gugus hidroksi-keto dan mendeteksi ada atau tidaknya 5-OH saja.

Spektrum UV senyawa hasil isolasi dengan penambahan $\mathrm{AlCl}_{3}$, terjadi pergeseran batokromik sebesar $57 \mathrm{~nm}$ dan pita II pergeseran batokromik sebesar $12 \mathrm{~nm}$, menunjukan tidak adanya gugus hidroksi yang berdekatan dengan gugus keton, dan gugus orto-dihidroksi pada cincin B. Hal ini diperkuat dengan tidak adanya pergeseran setelah penambahan $\mathrm{AlCl}_{3} / \mathrm{HCl}$.

Penambahan pereaksi geser yaitu $\mathrm{NaOAc}$ merupakan basa yang lebih lemah dari pada $\mathrm{NaOMe}$, karena itu spektrum $\mathrm{NaOAc}$ hanya dapat mendeteksi ada atau tidaknya gugus hidroksi yang paling asam, terutama untuk gugus 7-OH atau yang setara. Spektrum $\mathrm{NaOAc} / \mathrm{H}_{3} \mathrm{BO}_{3}$ berguna untuk mendeteksi ada atau tidaknya gugus orto-dihidroksi antara 2 gugus hidroksi paling asam berdekatan $(6,7-\mathrm{OH}$ atau 7,8-OH pada cincin A dan 3',4'-OH pada cincin $\mathrm{B}$ ), karena $\mathrm{NaOAc} / \mathrm{H}_{3} \mathrm{BO}_{3}$ menjembatani kedua gugus tersebut.

Dari spektrum UV senyawa hasil isolasi dengan penambahan $\mathrm{NaOAc}$ didapatkan pergeseran batokromik sebesar $2 \mathrm{~nm}$, hal ini diperkirakan karena adanya 7-OH. Setelah penambahan $\mathrm{NaOAc} / \mathrm{H}_{3} \mathrm{BO}_{3}$ terjadi pergeseran batokromik sebesar $53 \mathrm{~nm}$ dan pita II pergeseran batokromik sebesar $14 \mathrm{~nm}$, diperkirakan karena adanya orto-dihidroksi pada cincin B. Data ini diperkuat dengan pereaksi geser $\mathrm{AlCl}_{3} / \mathrm{HCl}$.

Mengacu pada hasil analisa preaksi geser terhadap spektrum UV senyawa hasil isolasi, maka diperkirakan bahwa senyawa ini termasuk jenis senyawa flavonol yang memiliki gugus hidrokksi pada posisi 7, 3' dan4'.

Spektrum IR senyawa hasil isolasi serapan melebar pada angka gelombang 3407,6 $\mathrm{cm}^{-1}$ yang merupakan gugus $\mathrm{OH}$ dan diperkuat 
dengan adanya serapan yang kuat pada daerah sidik jari $1054 \mathrm{~cm}^{-1}$, yang Khas untuk gugus CO alkohol.

Munculnya serapan pada angka gelombang 1663,3 $\mathrm{cm}^{-1}$ menindikasikan adanya gugus $\mathrm{C}=\mathrm{O}$, yang khas untuk keton siklik. Pada angka panjang gelombang $1610 \mathrm{~cm}^{-1}$ memperlihatkan adanya gugus $\mathrm{C}=\mathrm{C}$ aromatik, adanya cincin benzen pada $409,8 \mathrm{~cm}^{-1}$, adanya C-H alifatis pada angka gelombang $2932 \mathrm{~cm}^{-1}$, dan pada angka gelombang $1026 \mathrm{~cm}^{-1}$ memperlihatkan adanya serapan stretching C-OC.

Senyawa hasil isolasi dengan kromatografi kertas 2 arah dengan eluen nbutanol:asam asetat:air (4:1:5) Rf 0,45 dan asam asetat $15 \% \operatorname{Rf} 0,48$. Pola noda yang dihasilkan dibandingkan indentik dengan flavonol-Oglikosida.

Berdasarkan hasil penerjemahan spektrum yang dihasilkan, senyawa hasil isolasi pada sistem deteksi UV, IR, dan KKt 2 arah menunjukan bahwa senyawa hasil isolasi merupakan senyawa flavonol yang memiliki gugus $\mathrm{OH}$ pada posisi 7, 3' dan 4'.

\section{KESIMPULAN}

Berdasarkan penelitian yang telah dilakukan terhadap biji kakao, maka dapat disimpulkan bahwa:

1. Hasil isolasi dari fraksi etil asetat diperoleh senyawa flavonoid berupa bubuk berwarna kuning, hasil kromatografi lapisan tipis dengan eluen n-heksana:etil asetat (5: 5) memberikan harga $\mathrm{Rf} 0,45$ menggunakan eluen n-heksana : etil asetat $(2: 8) \mathrm{Rf} 0,55$ dengan eluen etil asetat : aseton $(5: 5) \operatorname{Rf} 0,75$ serta etil asetat : metanol $(1: 1) \operatorname{Rf} 0,88$.

2. Senyawa hasil isolasi dengan kromatografi kertas dua arah didapatkan $\mathrm{Rf} 0,45$ menggunakan eluen BAA (4:1:5) dan Rf 0,48 menggunakan eluen asam asetat $15 \%$.

3. Analisa data pemeriksaan kimia, kromatografi kertas 2 arah, spektrometri UV dan IR disimpulkan bahwa senyawa hasil isolasi adalah senyawa flavonoid golongan flavonol.

4. Analisa spektrum UV dengan pereaksi geser menunjukkan bahwa senyawa flavon memiliki gugus $\mathrm{OH}$ pada posisi $\mathrm{C}_{7}, \mathrm{C}_{3}$, dan $\mathrm{C}_{4}$.
Untuk lebih sempurnanya penelitian ini, maka dapat disarankan penelitian ini lebih lanjut melakukan pengukuran spektroskopi massa dan spektroskopi NMR serta uji efek fisiologis dan farmakologis terhadap senyawa hasil isolasi.

\section{DAFTAR RUJUKAN}

Achmad, S.A., E.H. Hakim dan L. Makmur. (1990). Flavonoid dan Phyto Medica, Kegunaan dan Prospek. Phyto Medica, Vol. I.

Cody, V. , E. Middleton, J. B. Harborne and A. Berezt. (1987). Flavonoids in Biology and Medicine II, Biochemical Celluler and Medicinal Properties. Alan R. Liss, Inc., New York.

Geissman, T. A.. (1962). The Chemistry of Flavonoid Compunds. Pergamon Press, New York.

Gunawan, D ., Dj. Wahyono, I. A. Donatus, Taroeno dan Mulyono. (1983). Risalah Simposium Penelitian Tumbuhan Obat III, Proceeding: Simposium Penelitian Tumbuhan Obat Indonesia, Yogyakarta, 12-15 September 1983, Fakultas Farmasi Universitas Gajah Mada, Yogyakarta

Harbone, J.B. (1987a). Metoda Fitokimia, Terbitan ke-2 ITB, Bandung.

Harbone, J. B. , T.J.. Mabry and H. Mabry. (1975) The Flavonoids, Chapman and Hall, London.

Harbone, J.B. (1987b). Phytochemical Methods (Metoda Fitokimia, Penuntun Cara Moderen Menganalisis Tumbuhan), Terbitan ke-2, diterjemahkan oleh Kosasih Padmawinata, Penerbit ITB, Bandung. 